\title{
Developments Of Self-Learning Module Basic Swimming College Students Of Sbmptn With Smnptn Pathway Pko Fik Unimed
}

\author{
Zulfan Heri ${ }^{1}$, M.Nustan Hasibuan ${ }^{2}$ \\ \{zulfan_heri67@yahoo.com ${ }^{1}$ \} \\ Sports Coaching Education Program State University of Medan ${ }^{12}$
}

\begin{abstract}
Learning is an effort to teach students to develop new knowledge and improve the quality of learning by applying independent learning to achieve the expected goals. To be able to produce quality learning has been done various ways through increasing human resources as educators, improving learning facilities and infrastructure, creating a good learning climate. The study explains how the implementation of independent learning conducted by FIK UNIMED students refers to the implementation of the KKNI curriculum that is running by comparing the results between students of SNPTN and SBMPTN to the learning outcomes of basic swimming courses. This study aims to produce an independent learning module conducted on the basic swimming courses conducted by students of the SNMPTN with the students of PKO SBMPTN FIK UNIMED. This research used research and development approach by producing products in the form of teaching materials based on competency standards through analysis of user needs. The results of this analysis underlie curriculum design to become the basis for compiling learning concepts in the form of self learning modules between SNMPTN students and SBMPTN. The results of the study produced independent learning modules in basic swimming courses and assessed the results of their application between students of SNMPTN and SBMPTN PKO FIK UNIMED.
\end{abstract}

Keywords: Self Learning SNMPTN with SBMPTN.

\section{Introduction}

In the 2016/2017 school year, UNIMED as one of the state university in Indonesia has implemented the IQF curriculum (Indonesian National Qualification Curriculum) is a competency qualification framework that can pair, equalize, and integrate between education and job training as well as work experience in order granting recognition of work competencies in accordance with the structure of work in various sectors. The design of the lecture standard of this IQF curriculum will be a reference for all lecturers in designing, implementing and evaluating the lecture processes carried out in the class. Advanced campuses must have lecture standards, although given the authority of the lecturers to arrange according to the characteristics of their respective study. If there are already standards for planning, implementing, and evaluating, the lecturer can only develop it to be carried out in lectures.

Creation of graduates who can meet the needs of the community is determined by various factors, including educator competence, students' abilities, facilities, facilities, curriculum, 
learning process, tools, college management, work environment and industrial cooperation, etc.. In this context prospective student admissions and curriculum play an important role.

In the implementation of the selection of new student admissions carried out by UNIMED as one of the state university conducted through the SNMPTN (Seleksi Nasional Masuk Perguruan Tinggi Negeri) and SBMPTN (Seleksi Bersama Masuk Perguruan Tinggi Nasional) began in 2008.

In the implementation of the Kurikulum Kualifikasi Nasional Indonesia (KKNI) conducted at FIK UNIMED, each department (study program) is required to take part in various sports practice courses, one of which is a basic and compulsory course that is swimming that requires success in mastering skills and knowledge in this matter cognitive abilities and sports motor skills.

The success of students in participating in the basic swimming course which is one of the branches of sports requires physical abilities that are influenced by past motion experience that is owned by each student of prospective students. In addition to the success of student learning is also determined by the interest in learning, intelligence, motivation and educational background that followed (S. Safarinah, 1986).

Self directed learning emphasizes more on students to be able to understand and understand what each student will do in the implementation of learning by referring to the modules that will be developed in this study. Here will be seen whether there are differences in the ability to carry out self-learning on the subject matter of swimming courses given to students. Based on the acceptance of new students of the Faculty of Sports Education UNIMED, for students who are accepted through with Seleksi Nasional Masuk Perguruan Tinggi Negeri (SNMPTN) will they have good basic swimming learning outcomes, and whether Seleksi Bersama Masuk Perguruan Tinggi Nasional (SBMPTN) path will have good swimming learning outcomes, to get answers, research was conducted on the development of independent learning modules for basic swimming courses between students of the SNMPTN and the SBMPTN PKO FIK UNIMED.

\section{Related research}

Self directed learning can be interpreted as a process on eye, where individuals take the initiative with or without the help of others. Activities carried out by these individuals include diagnosing learning needs, formulating learning objectives, identifying learning resources, selecting and implementing learning strategies and assessing learning outcomes.

According to Knowles (1975), self direct learning is more emphasized on adults with the assumption that the more mature students are:

1. The concept of themself is increasingly changing from an attitude of dependence on educators to self-directing and mutual learning among them.

2. Increasingly their learning experiences also can be used as learning resources, while learning orientation changes from mastery of the material towards problem solving.

3. Learning readiness is increasingly felt to master tasks related to their role in life.

4. The time perspective is increasingly oriented towards the use of learning outcomes that can be immediately utilized in life.

5. More involvement is needed in planning, need diagnosis, determining learning objectives, and evaluating learning processes and outcomes.

Self directed learning is very important for one's development because: 
1. People who take the initiative in learning more and better than people who depend on the educators.

2. This way of learning is in line with the natural process of soul development.

3. The emergence of new concepts or theories in education that emphasize the learning responsibilities of students.

The concept of self directed learning basically emphasizes the creativity and initiative of students. However, in certain conditions, students can systematically ask for assistance / guidance to educators, here the role of educators is more pressing as a facilitator.

The factors that influence self-study readiness are:

1. Open to every learning opportunity, learning is basically not limited by time, place or age. It can be said that learning is unlimited (no limit to learn), every time someone feels that the knowledge and experience they have is no longer able to solve the problem so that it encourages them to continue learning.

2. Having a self-concept as an effective learning citizen, someone who has self-concept means always perceives positively about learning and always strives for good learning outcomes.

3. Initiate and feel free in learning, initiative is an urge that arises from a person without being influenced by others, someone who has the initiative to learn does not need to be stimulated to learn.

4. Having a love for learning, making learning as part of human life starts from the emergence of awareness, intimacy, and love of learning.

5. Creativity. Creativity can be seen in terms of results, processes, characteristics, and attitudes.

According to Supardi (1994), creativity is the ability of a person to give birth to something new, whether in the form of ideas or real work that is relatively different from what was before. Ability to use fundamental learning skills and solve problems. Have a future orientation. Someone who has an orientation in the future will see that the future is not something that contains uncertainty.

\section{Method}

\section{Place and time of research}

This research was carried out at the Faculty of Sports Education of UNIMED precisely to students of the Sport Coaching Education (PKO) study program. Research time is planned for the odd semester of the 2018 - 2019 learning year.

\subsection{Research subject}

To conduct a needs analysis, observations were made of 3 basic swimming lecturers in the UNIMED Faculty of Sport Education, plus 1 swimming expert and 2 physical and sports education teachers. PKO students 35 people.

\subsection{Research methods}

This study uses a research and development approach or development research. This study begins with an analysis of the needs of users as material for re-designing the curriculum. 
Continued by gathering materials to compile teaching materials in the form of self learning modules.

\subsection{Research procedure}

This research was conducted to produce teaching material products in the form of independent learning modules for basic swimming courses. Activities carried out include the activities of preparing learning modules to establish needs analysis by collecting data from stakeholders, physical and sports education teachers, lecturers of basic swimming courses related to the curriculum (syllabus and RPS) used so far. Data was also collected from stakeholders, physical and sports education teachers, caregivers of basic swimming courses. The preparation of independent learning modules still takes into account the sequence and depth of the subject matter. The data that has been compiled is then presented in the seminar to produce teaching materials in the form of independent learning modules that are good and in accordance with the demands of competence. Furthermore, this material is carried out in the learning process in the odd semester of 2018-2019 learning year for students of SNMPTN and SNMPTN1. 


\section{References}

[1] Safarinah.: Psikologi Olahraga. Buku Tuntunan Dep P \& K, Jakarta (1986)

[2] Surakhmad.: Sari Dedaktik Metedologi Pengajaran Nasional. Jenmars, Bandung (1982)

[3] Sudjan.: Metode Statistik.Tarsito, Bandung (1986)

[4] Soejoko Hendromartono.: Olahraga Pilihan Renang. Depdikbud. Proyek Pembinaan Tenaga Kependidikan, (1992)

[5] Thomas, David. G.: Renang Tingkat Mahir. PT. Rajagrafindo, Jakarta (1996)

[6] Tempo, Co.: Beda SNMPTN dan SBMPTN, Jakarta (2018) 